$1-19-2021$

\title{
Protected Concerted Activity and Non-Unionized Employee Strikes: Worker Rights in Canada in the Time of COVID-19
}

Sara J. Slinn

Osgoode Hall Law School of York University

Follow this and additional works at: https://digitalcommons.osgoode.yorku.ca/ohlj

Part of the Law Commons

Article

\section{Citation Information}

Slinn, Sara J.. "Protected Concerted Activity and Non-Unionized Employee Strikes: Worker Rights in Canada in the Time of COVID-19." Osgoode Hall Law Journal 57.3 (2021) : 605-635.

https://digitalcommons.osgoode.yorku.ca/ohlj/vol57/iss3/4

This Article is brought to you for free and open access by the Journals at Osgoode Digital Commons. It has been accepted for inclusion in Osgoode Hall Law Journal by an authorized editor of Osgoode Digital Commons. 


\title{
Protected Concerted Activity and Non-Unionized Employee Strikes: Worker Rights in Canada in the Time of COVID-19
}

\author{
Abstract \\ During the pandemic employees in the US have engaged in a wave of strikes, protests, and other \\ collective action over concerns about unsafe working conditions, and many of these involved non- \\ unionized workers in the private sector. Similar employee protests were notably absent in Canada. This \\ article examines the differences in labour legislation between the US and Canada, which may help to \\ explain these diverging experiences, primarily: the National Labor Relations Act (NLRA) section 7 \\ protection for concerted activity, and the NLRA section 502 ability for a good faith strike due to \\ abnormally dangerous conditions for work. This article outlines and compares the situation of, and \\ consequences for, three categories of workers engaging in a strike over fears of workplace safety: \\ unionized employees, non-unionized employees, and non-employees, such as independent contractors \\ under the NLRA compared to under the Ontario Labour Relations Act (OLRA), as generally representative \\ of Canadian labour legislation. In the final section, this article considers how a statutory provision similar \\ to the NLRA protected concerted activity provision might be incorporated into Canadian labour legislation \\ such as the OLRA. It also considers some more fundamental questions that such changes might prompt \\ policymakers to reconsider, including: the focus of our statutory system on "organizing" collective action \\ to the exclusion of "mobilizing" collective action, and questions about the potential role of minority \\ unionism in our labour legislation system.
}




\title{
Protected Concerted Activity and Non-Unionized Employee Strikes: Worker Rights in Canada in the Time of COVID-19
}

\author{
SARA J. SLINN
}

During the pandemic employees in the US have engaged in a wave of strikes, protests, and other collective action over concerns about unsafe working conditions, and many of these involved non-unionized workers in the private sector. Similar employee protests were notably absent in Canada. This article examines the differences in labour legislation between the US and Canada, which may help to explain these diverging experiences, primarily: the National Labor Relations Act (NLRA) section 7 protection for concerted activity, and the NLRA section 502 ability for a good faith strike due to abnormally dangerous conditions for work. This article outlines and compares the situation of, and consequences for, three categories of workers engaging in a strike over fears of workplace safety: unionized employees, non-unionized employees, and non-employees, such as independent contractors under the NLRA compared to under the Ontario Labour Relations Act (OLRA), as generally representative of Canadian labour legislation. In the final section, this article considers how a statutory provision similar to the NLRA protected concerted activity provision might be incorporated into Canadian labour legislation such as the OLRA. It also considers some more fundamental questions that such changes might prompt policymakers to reconsider, including: the focus of our statutory system on "organizing" collective action to the exclusion of "mobilizing" collective action, and questions about the potential role of minority unionism in our labour legislation system.

Associate Professor and Associate Dean (Research and Institutional Relations), Osgoode Hall Law School, York University. 
I. NON-UNIONIZED EMPLOYEE STRIKES IN THE UNITED STATES

II. WHAT ABOUT CANADIAN WORKERS?.....

III. NLRA PROTECTION FOR CONCERTED ACTIVITY AND FROM ABNORMALLY DANGEROUS CONDITIONS

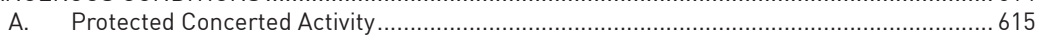

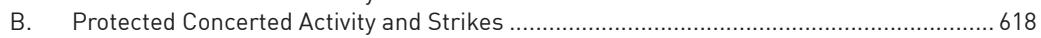

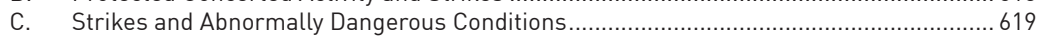

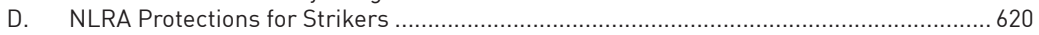

IV. EMPLOYEE FREEDOMS AND STRIKES UNDER CANADIAN LABOUR LAW ...............................6...621

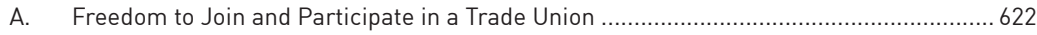

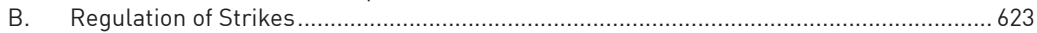

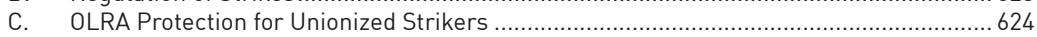

D. Strikes by Non-Unionized Workers under the OLRA ..............................................626

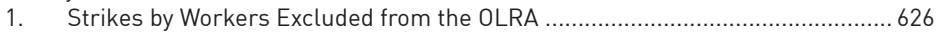

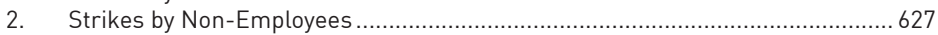

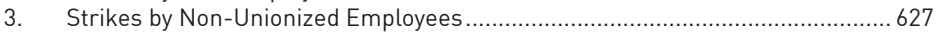

V. REVISITING PANDEMIC-RELATED STRIKES IN THE UNITED STATES AND CANADA..................628

VI. CONTEMPLATING PROTECTED CONCERTED ACTIVITY FOR CANADIAN EMPLOYEES .................630

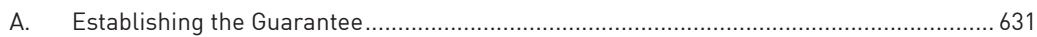

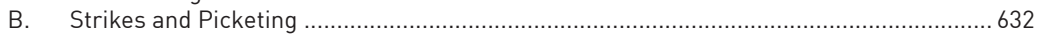

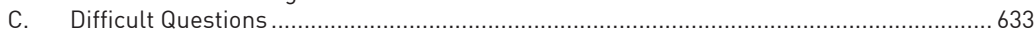

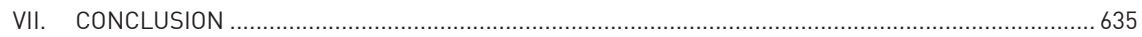

WORKERS AROUND THE GLOBE have been engaging in a startling wave of strikes, protests, and other collective action over concerns about unsafe working conditions during the COVID-19 pandemic. Many of these actions have taken place in the United States, across a wide array of sectors and occupations, including retail, grocery, delivery, fast food, food processing, manufacturing, postal, transit, and health care. ${ }^{1}$ Many of these collective worker actions involve some of the largest and most powerful corporate international employers, such as Amazon, McDonald's, and Whole Foods, as well as smaller enterprises. Remarkably, many of these actions have taken place in the private sector by non-unionized

1. See e.g. Steven Greenhouse, "Is Your Grocery Delivery Worth a Worker's Life?," The New York Times (30 March 2020), online: <nytimes.com/2020/03/30/opinion/coronavirus-workerstrike.html> [perma.cc/672Q-FL2F] (providing an overview of US worker safety strikes); Bridget Read, "Every Food and Delivery Strike Happening Over Coronavirus" (27 May 2020), online: <thecut.com/2020/05/whole-foods-amazon-mcdonalds-amongcoronavirus-strikes.html> [perma.cc/L5ZC-3DF5]; Christopher Weber, "Work safety strike, virus lockdown protest set for May Day," CTV News (1 May 2020), online: <ctvnews.ca/world/work-safety-strike-virus-lockdown-protest-set-for-may-day-1.4920157> [perma.cc/J4TH-PK5J]. 
workers. Perhaps most surprising of all is that some of these efforts have been effective, leading to improved working conditions for these workers, at least for the moment. ${ }^{2}$

The events in the US were widely reported in Canada, involving as they did many prominent companies that also operate with many employees in many locations in this country. This prompted several journalists to ask whether similar strikes and actions were planned at these companies' Canadian workplaces and why their Canadian employees weren't also engaging in such strikes. ${ }^{3}$ As a recent media article asks: "U.S. Workers are Organizing Mass Strikes. Why Aren't Canadian Workers?"4

This article addresses this question. In particular, it considers whether differences in labour legislation between the two countries help to explain why non-unionized employees in the US but not in Canada have been engaging in these strikes, and the relatively subdued actions of even unionized employees in this country. It first examines and compares worker actions during the pandemic in the US and in Canada. Next, it examines the relevant provisions of the US National Labor Relations Act (NLRA) underlying these non-union strikes, focusing on that Act's protected concerted activity provision, which is not found in Canadian labour statutes. ${ }^{5}$ To highlight the differences between the US and Canadian legal contexts, it outlines and compares the situation of, and consequences for, three categories of workers engaging in a strike over

2. See e.g. Shirin Ghaffary, "The May Day strike from Amazon, Instacart, and Target workers didn't stop business. It was still a success" (1 May 2020), online: <vox.com/recode/2020/ 5/1/21244151/may-day-strike-amazon-instacart-target-success-turnout-fedex-protestessential-workers-chris-smalls> [perma.cc/ZKN9-4NRX]; Hannah Jackson \& Maryam Shah, "Instacart announces coronavirus protections amid threats of a strike," Global News (29 March 2020), online: <globalnews.ca/news/6748137/coroanvirus-instacart-strike> [perma. cc/H7VL-GHRL]; Greenhouse, supra note 1; Kate Taylor, "The workers that make your food put their lives on the line during pandemic. Whether they're protected now is up to you," Business Insider (25 May 2020), online: <businessinsider.com/workers-new-benefits-in-thepandemic-will-they-keep-them-2020-5> [perma.cc/6VGK-MRLT].

3. See e.g. Zaid Noorsumar, "U.S. workers are organizing mass strikes. Why aren't Canadian workers?” Vice (13 May 2020), online: <vice.com/en_ca/article/88998z/amazon-workers-areorganizing-strikes-in-the-us-why-arent-canadian-workers> [perma.cc/U4QP-KD9E]; The Associated Press, "U.S. Amazon and Instacart workers strike to protest COVID-19 hazards on the job," CBC News (31 March 2020), online: <cbc.ca/news/business/amazon-instacardcoronavirus-1.5515868> [perma.cc/2H78-VGTH] (reporting that, when asked, organizers of planned US-wide Whole Foods employee strike said they were "unaware of any plans for similar actions in Canada").

4. Noorsumar, supra note 3.

5. National Labor Relations Act, 29 USC ss 151-69 (1935) at ${ }^{\S} 157$ [NLRA]. 
fears of workplace safety: unionized employees, non-unionized employees, and non-employees, such as independent contractors under the NLRA compared to under the Ontario Labour Relations Act (OLRA), as generally representative of Canadian labour legislation. ${ }^{6}$ In the final section, this article considers how a statutory provision similar to the NLRA protected concerted activity provision might be incorporated into Canadian labour legislation, such as the OLRA. It also considers some uncomfortable questions that may need to be addressed about the nature and scope of our labour relations systems. These include questions about the fundamental type of collective action recognized by our labour relations system, and questions about a potential role for minority unionism. This article focuses on statutory labour law and does not address treatment of employees' refusal to work pursuant to occupational health and safety legislation. ${ }^{7}$

\section{NON-UNIONIZED EMPLOYEE STRIKES IN THE UNITED STATES}

As noted in the introduction, non-unionized employees across many companies, industries, and occupations in the US have taken part in strikes and other forms of collective action during the pandemic out of fear of unsafe workplaces. In many cases, these were also accompanied by complaints of retaliation against those workers leading or participating in these activities. One of the most prominent examples, involving Amazon, is briefly described below, to offer a sense of what has been occurring and as a basis for comparison with events in Canada at the workplaces of this same company and others.

Amazon workers at many locations in the US have engaged in demonstrations and walk-out strikes, demanding better working conditions, such as protective equipment, improved sick leave, and sanitizing of facilities. A widely publicized example involved an Amazon worker, Chris Smalls, fired hours after organizing a strike at an Amazon warehouse on Staten Island to protest the lack of safety protection for employees. Amazon contends that he was terminated for misconduct; Smalls says it was retaliation. ${ }^{8}$ Amazon employee actions in Chicago have also garnered attention. There, workers have engaged in petitions, walk-out strikes, and work slowdowns to protest their pandemic working

6. Labour Relations Act, 1995, SO 1995, c 1, Sched A [OLRA].

7. See e.g. Occupational Health and Safety Act, RSO 1990, c O.1 [OHSA].

8. Sarah Jones, "Workers are trying to prevent a deadly COVID-19 disaster," New York Magazine (9 April 2020), online: <nymag.com/intelligencer/2020/04/protesting-workers-aretrying-to-save-lives.html> [perma.cc/7PGG-DFXK]. 
conditions. ${ }^{9}$ Employee leaders were terminated in what DCH1 Amazonians United, a non-union worker group, claims was targeted retaliation against these employees. This group has since filed multiple complaints with the National Labor Relations Board (NLRB), claiming interference with these employees' right to engage in protected concerted activity. ${ }^{10}$

Similar episodes of non-unionized employee strikes seeking safe work conditions - both at individual workplaces as well as nation-wide, and involving multiple workplaces and companies—have been taking place during the pandemic at McDonald's, Whole Foods, and many other workplaces. As with Amazon, some of these episodes have also resulted in employment repercussions for the employees involved. ${ }^{11}$

Important to the discussion in this article, and our comparison with the Canadian situation, is that in many of these cases, including the Amazon example, employees, or organizations on their behalf, have brought unfair labour practice (ULP) complaints against their employers, pursuant to section $8(a)(1)$ of the NLRA to protect striking employees from negative consequences for these actions. These ULPs claim that the employer "interfere[d] with, restrain[ed], or coerce[d] employees in the exercise of the rights guaranteed in section 7 [of the NLRA]." ${ }^{12}$ Section 7 guarantees employees the right to engage in "protected concerted activity" for "mutual aid or protection," stating that:

9. Amazonians United, "How Amazon Workers are Organizing for the Long Haul" (11 May 2020), online: <www.labornotes.org/2020/05/how-amazon-workers-are-organizing-longhaul> [perma.cc/G6LN-YH5H]; Caroline O'Donovan, “The NLRB is Looking into Claims that Amazon Violated Employees' Rights During the Coronavirus Pandemic" (18 April 2020), online: <www.buzzfeednews.com/article/carolineodonovan/federal-labor-regulatorsare-looking-into-claims-that> [perma.cc/DT5J-4UE].

10. Amazonians United, supra note 9; O'Donovan, supra note 9. The NLRB administers and enforces the NLRA.

11. See e.g. Jones, supra note 8; Greenhouse, supra note 1; Lauren Kaori Gurley, "Fast Foods Workers at 50 Restaurants Across California Are Going on Strike" Vice (8 April 2020), online: <vice.com/en_us/article/7kzyxz/fast-foods-workers-at-30-restaurants-acrosscalifornia-are-going-on-strike> [perma.cc/F4GH-VB8H]; Matt Day, "Whole Foods Workers Launch Sickout Protest. How Many Isn't Clear” (31 March 2020), online: <bloomberg.com/ news/articles/2020-03-31/whole-foods-workers-launch-sick-out-protest-how-many-isn-tclear> [perma.cc/G5YJ-UDYD].

12. NLRA, supra note $5,{ }^{\S} 7,8(\mathrm{a})(1)$. As of 10 July 2020 , multiple section 8(a)(1) ULP charges have been filed against Amazon and McDonald's restaurants and one has been filed against Whole Foods. See O’Donovan, supra note 9; Tyler Sonnemaker, "Amazon is facing multiple inquiries from labor regulators into whether it unlawfully retaliated against workers who spoke out about its coronavirus response," Business Insider (20 April 2020), online: $<$ businessinsider.com/amazon-nlrb-inquiries-workers-protests-coronavirus-warehouseconditions-2020-4> [perma.cc/J83T-PY2X]. 
Employees shall have the right to self-organization, to form, join, or assist labor organizations, to bargain collectively through representatives of their own choosing, and to engage in other concerted activities for the purpose of collective bargaining or other mutual aid or protection.

\section{WHAT ABOUT CANADIAN WORKERS?}

Canadian media reporting on concerted actions by Whole Foods employees in the US also reported on the lack of similar actions by workers at this company in Canada. ${ }^{13}$ Reporting on Amazon worker strikes, a journalist posed the question, "U.S. Workers Are Organizing Mass Strikes. Why Aren't Canadian Workers?"14

Indeed, there have been no media reports of strikes by employees in Canada during the pandemic at any of the prominent companies where we have seen worker action in the US, such as Amazon, McDonald's, and Whole Foods. It is unlikely, however, that this is due to a lack of employee concerns about their workplace safety. There are reports of dissatisfaction with workplace conditions during the pandemic from Amazon workers in Canada, for example. In addition to an online petition in support of non-unionized Amazon workers in the Greater Toronto Area circulated by the non-union Warehouse Workers Centre organization, some of these workers have spoken to media at various times about their health and safety concerns, but did so confidentially and anonymously "because they say they fear losing their job for speaking out," 15 "feared reprisal for speaking to the media," 16 and with one worker saying "he's certain he would be terminated if Amazon knew he had gone public with his concerns. 'You'd lose your

13. See Jackson \& Shah, supra note 2 ("It's not clear ... whether a potential strike [by Instacart workers] would extend into Canada"); The Associated Press, "U.S. Amazon and Instacart workers strike to protest COVID-19 hazards on the job," CBC News (31 March 2020), online: <cbc.ca/news/business/amazon-instacard-coronavirus-1.5515868> [perma.cc/ BW8T-SUE8] ("Whole Worker, a workers group for Whole Foods employees, is calling for a country-wide 'sick out'.... CBC News has been in touch with one of the organizers of the strike in the U.S., who said she was unaware of any plans for similar actions in Canada").

14. Noorsumar, supra note 3.

15. Philippe de Montigny, "Amazon employees flag health concerns in Canadian warehouses," CBC News (27 April 2020), online: <cbc.ca/news/canada/toronto/amazon-covid19-ca nada-1.5540594> [perma.cc/6LLV-PLJ8].

16. Sara Mojtehedzadeh, "As online orders surge, what about the Amazon workers?," The Toronto Star (19 March 2020), online: <thestar.com/news/canada/2020/03/19/as-online-orderssurge-what-about-the-amazon-workers.html> [perma.cc/S4LH-MF8M]. 
job for sure." ${ }^{17}$ More generally, concerns have been raised about the availability and adequacy of employees' ability to refuse unsafe work under occupational health and safety legislation. ${ }^{18}$ Therefore, exploring the potential for employees to utilize labour law to engage in self-help to secure safe working conditions, as employees have been doing in the US, may be an important consideration for ensuring adequate and timely workplace protection for Canadian employees.

While private sector, non-unionized workplaces in Canada have not seen the types of collective employee action that has been prominent in similar workplaces in the US during the pandemic, some protests by workers seeking safer workplaces or access to pandemic pay have occurred, although these appear to be uncommon. Where employee actions have occurred, several differences from the US experience are evident. First, in Canada, typically public sector, unionized employees have been involved, as opposed to non-unionized, private sector employees as has been the case in the US. The nature of the action has also been different: not only are Canadian employees rarely striking, but in some cases employees or their organizations have taken pains to emphasize that their actions are not strikes.

In the public sector, for example, unionized transit workers in Toronto, Montreal, and Edmonton held spontaneous walk-outs or threats of strikes over

17. Sean O'Shea, "Ontario Amazon whistleblower says company didn't disclose coronavirus case to all," Global News (5 May 2020), online: <globalnews.ca/news/6905042/ coronavirus-amazon-brampton-warehouse-covid-19> [perma.cc/JZR3-2AEV].

18. While the number of work refusals under the OHSA, RSO 1990, c O.1 in the province rose during the pandemic, the Ministry of Labour, Training and Skills Development has been subject to criticism for upholding only one of the 280 cases arising between January and June 2020. Critics claim the Ministry has not taken worker concerns seriously. See Sara Mojtehedzadeh, "Many Ontario workers are trying to refuse work due to COVID-19 fearsbut the government isn't letting them," The Toronto Star (27 April 2020), online: <thestar. com/business/2020/04/27/many-ontario-workers-are-trying-to-refuse-work-due-to-covid-19fears-but-the-government-isnt-letting-them.html> [perma.cc/VFE8-AGBD]; Inayat Singh, "More Canadians are refusing work due to COVID-19-but it's tough to get authorities to agree," CBC News (22 June 2020), online: <cbc.ca/news/canada/ work-refusal-safetycovid-1.5617787> [perma.cc/5TEP-ZYD2]; Canadian Federation of Nurses Unions, "Nurses launch investigation into Canada's failure to protect health care workers from COVID-19" (22 June 2020), online: <nursesunions.ca/nurses-launch-investigation-intocanadas-failure-to-protect-health-care-workers-from-covid-19> [perma.cc/9ZVF-ES7U]. Although the occupational health and safety regime may be available to address workers' health and safety concerns, this article does not address that regime. 
demands for safe working conditions and increased testing, ${ }^{19}$ while unionized hospital workers have held several Ontario-wide days of action in response to the lack of access to pandemic pay for all hospital workers. These protests have not involved strikes, but rather the collective wearing of stickers, and holding up of signs at coordinated times, ${ }^{20}$ and rallies by workers during non-working hours. ${ }^{21}$ Work stoppages have been rare. ${ }^{22}$ Notably, some doctors were reported to have discussed, in private Facebook groups, the possibility of refusing to work due to the lack of protective equipment. ${ }^{23}$ At a residential care home in Markham, the majority of staff walked out after management informed them that a number of

19. Carl Bronski, "Walkouts by Canadian transit workers protest lack of COVID-19 protections" World Socialist Web Site (20 April 2020), online: <wsws.org/en/articles/2020/04/20/ttcw-a20. html> [perma.cc/5TZU-93BM]; Bryann Aguilar, "Eight TTC maintenance workers walk off job as union demands more COVID-19 testing," CTV News (18 April 2020), online: $<$ toronto.ctvnews.ca/eight-ttc-maintenance-workers-walk-off-job-as-union-demands-morecovid-19-testing-1.4902579> [perma.cc/N9U4-X5ME].

20. Aguilar, supra note 19; Canadian Union for Public Employees, "CUPE, SEIU, and UNIFOR will Hold Day of Action on June 17 Calling for Pandemic Pay for All Hospital Workers" (15 June 2020), online: <cupehospitals.ca/news/cupe-seiu-and-unifor-will-hold-day-of-actionon-june-17-calling-for-pandemic-pay-for-all-hospital-workers> [perma.cc/Q9XD-29FF]; Taylor Blewett, "Ottawa hospital workers protest exclusion from pandemic pay," Ottawa Citizen (2 June 2020), online: <ottawacitizen.com/news/local-news/ottawa-hospitalworkers-protest-exclusion-from-pandemic-pay> [perma.cc/NKZ8-72VU]; Ted Raymond, "Health-Care Workers at Queensway Carleton to Protest Thursday for Expanded Pandemic Pay in Hospitals" (14 May 2020), online: <iheartradio.ca/newstalk-1010/news/ health-care-workers-at-queensway-carleton-to-walk-out-thursday-in-support-of-expandedpandemic-pay-1.12410178> [perma.cc/9Y52-Z2PV]; Ontario Council of Hospital Unions \& Canadian Union of Public Employees, "Day of Action-May 6" (5 May 2020), online: <ochu.on.ca/2020/05/05/day-of-action-may-6> [perma.cc/H57A-FNRL].

21. Blewett, supra note 20; Raymond, supra note 20; 101.3 myFM News staff, "COVID-19: Hospital workers strike due to lack of pandemic pay,” 101.3 Milton Now (14 May 2020), online: <www.miltonnow.ca/2020/05/14/covid-19-hospital-workers-strike-due-to-lack-ofpandemic-pay> [perma.cc/YM5J-TFTR].

22. СBC News, "'State of emergency' at Markham facility for adults with disabilities after staff walk away over COVID-19," CBC News (10 April 2020), online: <cbc.ca/news/ canada/ toronto/participation-house-critical-need-ppe-staff-1.5529384> [perma.cc/87MU-LQL9]; 101.3 myFM News staff, supra note 21.

23. Stephen Maher, "Fear and anger on the frontlines: What happens if there aren't enough masks?" Maclean's (30 March 2020), online: <macleans.ca/news/canada/fear-and-anger-onthe-frontlines-what-happens-if-there-arent-enough-masks> [perma.cc/4RJG-RWUJ] ("Some Canadian doctors are talking about walking off the job if they're not provided with adequate equipment to protect themselves from infection"). Physicians in Canada are not unionized, although provincial medical associations engage in collective representation and bargaining on behalf of physicians. 
residents and staff had contracted COVID-19. However, a union representative publicly stated that " $[t]$ his was not a mass action, not a job action, not a strike." 24

There have been some instances of private sector, unionized employees taking action. ${ }^{25}$ Perhaps most prominent has been the case of unionized meat-packing employees. By early May 2020, Cargill's High River Alberta meat-packing facility was reported to be the site of North America's largest COVID-19 outbreak. ${ }^{26}$ An early request for a stop work order from Alberta Occupational Health and Safety was denied. ${ }^{27}$ In early May, as the plant moved towards re-opening following temporary closure after the COVID-19 death of a worker, a multi-day protest was held outside the High River plant, with participants from the employees' union, the United Food and Commercial Workers Union (UFCW), and other union organizations. ${ }^{28}$ Notably, the UFCW stated "[w]e're not on strike and we're not asking people not to go to work." ${ }^{29}$ The UFCW has also filed a ULP complaint against the employer and the provincial government. ${ }^{30}$

24. CBC News, supra note 22.

25. Michael Wayland, "Work stoppage over coronavirus fears temporarily shuts down Fiat Chrysler plant in Canada," CNBC (13 March 2020), online: <www.cnbc.com/2020/03/13/ coronavirus-fiat-chrysler-plant-workers-walk-out-in-canada.html> [perma.cc/C7M5-XTFA] (automotive plant workers engaged in one-day strike over fears of infected co-worker); Nina Grossman, "No sanitization, no workers: Victoria tradespeople walk off job," Nanaimo News Bulletin (21 March 2020), online: <www.nanaimobulletin.com/news/no-sanitization-noworkers-victoria-tradespeople-walk-off-job> [perma.cc/3DMX-L9KE] (construction workers walked-off sites objecting to unsanitary working conditions).

26. "Meat Packers say Cargill Ignored their Concerns about Deadly COVID-19 Outbreak at Alberta Slaughterhouse," Press Progress (14 May 2020), online: <pressprogress.ca/ meat-packers-say-cargill-ignored-their-concerns-about-deadly-covid-19-outbreak-at-albertaslaughterhouse> [perma.cc/2BUL-J2RJ].

27. Kathryn Blaze Baum, Carrie Tait \& Tavia Grant, "How Cargill became the site of Canada's largest single outbreak of COVID-19," The Globe and Mail (3 May 2020), online: <www. theglobeandmail.com/business/article-how-cargill-became-the-site-of-canadas-largest-singleoutbreak-of> [perma.cc/UEN4-GFN2].

28. Stephanie Thomas, "Protests continue at Alberta's Cargill meat processor where 949 workers tested positive for COVID-19," CTV News (6 May 2020), online: <calgary.ctvnews.ca/ protests-continue-at-alberta-s-cargill-meat-processor-where-949-workers-tested-positive-forcovid-19-1.4927353> [perma.cc/JJ39-MTXY].

29. Kaylen Small, Adam MacVicar \& Melissa Gilligan, "Coronavirus: Cargill meat-packing plant in High River, Alta., reopens amid ongoing talks with union," Global News (3 May 2020), online: <globalnews.ca/news/6900280/coronavirus-cargill-union-talks-alberta> [perma.cc/59B2-G46H].

30. United Food and Commercial Workers Canada Union, Local No $401 v$ Cargill Limited and Government of Alberta (1 May 2020), online: <gounion.ca/wp-content/uploads/2020/05/ UFCW-ULP-Complaint-to-ALRB-2020-05-01.pdf> [perma.cc/J2MK-3V3T]. As of this writing, a decision has not been issued in this matter. 
Overall, what we have not seen in Canada are strikes by non-unionized, private sector employees as a widespread phenomenon, which has been among the most notable features of the phenomenon in the US. ${ }^{31}$

\section{NLRA PROTECTION FOR CONCERTED ACTIVITY AND FROM ABNORMALLY DANGEROUS CONDITIONS}

The NLRA is the primary collective bargaining statute in the US, applicable to most of the private sector, providing rights and protections to workers who satisfy the statutory definition of "employee." ${ }^{2}$ While the NLRA is commonly criticized as being less protective of employee collective rights than is Canadian labour law, ${ }^{33}$ not only does the NLRA differ from Canadian labour legislation in several ways, but in some key respects it offers greater protection to fundamental employee rights. ${ }^{34}$

First, as Michael Duff has recently pointed out, it is a common, but mistaken, belief that the NLRA applies only to unionized employees and workplaces. ${ }^{35}$ Neither unionization, nor the intention to unionize, is a requirement for access to NLRA protections. ${ }^{36}$ The NLRA offers protection to non-unionized, private

31. Robert Combs, "Analysis: COVID-19 Has Workers Striking. Where Are the Unions?" (14 April 2020), online: <news.bloomberglaw.com/bloomberg-law-analysis/analysis-COVID-19has-workers-striking-where-are-the-unions> [perma.cc/7KKE-UKGZ].

32. Excluded employees (such as public sector, agricultural and domestic workers, managers and supervisors, railway and airline workers) and non-employee workers (such as independent contractors) fall outside the scope of the NLRA and have no to access to its protections. See $N L R A$, supra note $5,{ }^{\S} 2(2)$. Public sector postal employees are an explicit exception to the NLRA's lack of coverage of public sector employees. See Postal Reorganization Act, 39 USC $\S 101$ (1970). Unlike Canadian labour law, discussed below, the NLRA does not regard dependent contractors as employees, thus they are excluded from the Act.

33. See e.g. Jeffrey Sack, "U.S. and Canadian Labour Law: Significant Distinctions" (2010) 25 ABA J Labor \& Employment 241 at 241, 257; Fergal O’Brien \& Zoe Schneeweiss, “U.S. Ranked Worst for Workers' Rights Among Major Economies” (18 June 2020), online: $<$ bloomberg.com/news/articles/2020-06-18/u-s-ranked-worst-for-workers-rights-amongmajor-economies> [perma.cc/6Y7B-Z6ZW].

34. Lance A Compa, "The Wagner Model and International Freedom of Association Standards" in Autonomie collective et droit du travail: Melanges en l'honneur du Professor Pierre Verge ed by Dominic Roux (Presses de l'Université Laval, 2014) 427 at 437.

35. Michael C Duff, "New Labor Viscerality? Work Stoppages in the 'New Work,' Non-Union Economy" 65 St Louis U LJ [forthcoming in 2021], online: <https://ssrn.com/abstract= $3637605>$, at 11.

36. See NLRB v Modern Carpet Indus, 611 F (2d) 811 at 813 (10th Cir 1979) [Modern Carpet]; Ontario Knife Co v NLRB, 637 F (2d) 840 at 843 (2d Cir 1980) [Ontario Knife]; NLRB v Washington Aluminum Co, 370 US 9 (1962) [Washington Aluminum]. 
sector employees, such as those engaging in the strikes and other collective actions we have seen during the pandemic. ${ }^{37}$ There are two primary sources of protection available under this legislation to both unionized and non-unionized employees engaging in concerted action (including strikes due to health and safety concerns), neither of which has a counterpart in Canadian labour legislation generally, or the OLRA specifically. These are the NLRA section 7 protected concerted activity provision and the section 502 abnormally dangerous work provision. As explained below, NLRA section 7 is of greater relevance to non-unionized employees, so is given greater attention here.

\section{A. PROTECTED CONCERTED ACTIVITY}

NLRA section 7 provides that " $[\mathrm{e}]$ mployees shall have the right to self-organization, to form, join, or assist labor organizations, to bargain collectively through representatives of their own choosing, and to engage in other concerted activities for the purpose of collective bargaining or other mutual aid or protection." ${ }^{38}$ These rights are held by individual employees, and apply to all employees within the scope of the NLRA, whether or not they are unionized or even seeking to unionize or engage in collective bargaining. ${ }^{39}$ These rights extend to efforts to improve working conditions through "channels outside the immediate employer-employee relationship," including "resort to administrative and judicial forums" and "appeals to legislators to protect their interests," ${ }^{30}$ which can apply even where employees have not approached their employers with specific demands or complaints before taking action, ${ }^{41}$ and employees need not be correct in whole or in part regarding the underlying complaint motivating their action, provided that they have acted in good faith. ${ }^{42}$

Limits to section 7 NLRA protection exist. Activity that is insubordinate, disobedient, disloyal, illegal, destructive, or engaged in in an abusive manner

37. Sheppard, Mullin, Richert \& Hampton LLP discussed an example of the lengthy list of employee actions related to COVID-19 workplace concerns that may fall within the scope of protected concerted activity. See Sheppard, Mullin, Richert \& Hampton LLP, "Labor Issues Concerning COVID-19 and Government 'Stay at Home' Orders” (20 March 2020), online: $<$ martindale.com/legal-news/article_sheppard-mullin-richter-hampton-llp_2527663.htm> [perma.cc/9JCG-BUFL].

38. NLRA, supra note $5,{ }^{\S} 157$.

39. NLRB v Magnavox Co of Tennessee, 415 US 322 (1974); Modern Carpet, supra note 36; Ontario Knife, supra note 36; Washington Aluminum, supra note 36.

40. Eastex Inc v NLRB, 437 US 556, 565-66 (1978).

41. See Washington Aluminum, supra note 36 at 14; NLRB v Empire Gas Inc, 566 F (2d) 681 at 684 (10th Cir 1977).

42. See Modern Carpet, supra note 36 at 814 . 
may not be protected, and a balancing test is applied to determine whether these limits have been reached. ${ }^{43}$ The NLRB has found that collective employee actions in protest over what employees honestly believe to be unsafe working conditions can be protected concerted activity within the meaning of section $7 .{ }^{44}$ To fall within section 7, the activity must be both "concerted" and for "mutual aid or protection." ${ }^{45}$ For activity to be considered "concerted," the NLRB requires "that it be engaged in with or on the authority of other employees, and not solely by and on behalf of the employee himself." ${ }^{\prime 6}$ However, activity need not be supported by a majority of employees to be "concerted." 47 "Individual griping and complaining" about an individual issue often fails to satisfy the "mutual aid or protection" requirement, in addition to failing to be concerted activity. ${ }^{48}$ This does not exclude the possibility of individual employee actions qualifying as concerted activity. In some circumstances, where it is not simply a complaint about a matter of concern to an individual, actions of individual employees may be considered to be concerted activity. Examples include where an individual, though not a designated spokesperson, brings a group complaint to the attention of management, and more generally, where there is evidence of group activities even if not "specifically authorized" in a formal sense; where individuals "seek to initiate or to induce or to prepare for group action"; where individuals bring "truly group complaints" to management's attention; and where individual activity is "looking toward group action." ${ }^{49}$ The NLRB recently clarified that "individual griping" does not constitute concerted activity simply where it occurs in the presence of other employees and management, and that it "includes the use of the first-person plural pronoun" unless it is truly a group complaint being

43. See Atlantic Steel, 245 NLRB 814 (1979); NLRB v IBEW Local No 1229, 346 US 464 (1953); Mastro Plastics Corp v National Labor Relations Bd, 350 US 270 (1956).

44. Tamara Foods Inc, 258 NLRB 1307 (1981) [Tamara]. "It has long been established that Section 7 of the Act protects the rights of employees to engage in protests, including work stoppages, over what the employees believe to be unsafe or unhealthy working conditions" (ibid at 1308).

45. Alstate Maintenance LLC, 367 NLRB No 68 at 2 (2019).

46. Meyers Industries, Inc, 268 NLRB 493 (1984) [Meyers I]; see also Ontario Knife, supra note 36 at 845 .

47. NLRB v Jasper Seating Co, 857 F (2d) 419 at 422 (7th Cir 1988) cited in Duff, supra note 35 at 11 ("Nothing in the Act, however, limits the rights of non-unionized employees to engage in concerted conduct for their mutual aid regardless of whether or not their goal is supported by a majority of employees").

48. Rita Gail Smith \& Richard A Parr II, "Protection of Individual Action as Concerted Activity under the National Labor Relations Act” (1982) 68 Cornell L Rev 369 at 375.

49. Meyers I, supra note 46; Ontario Knife, supra note 36 at 844-45; Meyers Industries Inc, 281 NLRB 882 at 886-87 (1986) [Meyers II]. 
brought to management's attention, or the "totality of the circumstances must support a reasonable inference that in making the statement, the employee was seeking to initiate, induce or prepare for group action." The NLRB identified several factors that would tend to support such an inference. ${ }^{50}$

The "mutual aid or protection" component of NLRA section 7 has been interpreted broadly such that it includes "almost any activity that somehow affects the well-being of the employees as a group." ${ }^{1}$ Though wide-reaching, this element is still meaningful as some concerted activities fail this second requirement because they have unprotected objectives that do not qualify as "mutual aid and protection." 52

ULP provisions, found in section 8, address violations of NLRA section 7 rights. While other section 8 ULPs may also apply in a particular case, section 8(a)(1) speaks specifically to section 7 , providing that an employer must not "interfere with, restrain, or coerce employees in the exercise of the rights guaranteed in section 7." 53 The NLRB General Counsel initially bears the burden of proving, prima facie, that protected concerted activity was a substantial or motivating factor in the employer's impugned action. ${ }^{54} \mathrm{~A}$ causal relationship must exist between the protected activity and the impugned employer action..$^{55}$ The burden then shifts to the employer to demonstrate that it would have engaged in the same action in the absence of the protected activity. ${ }^{56}$ Employer action partially motivated by the protected activity will be sufficient to find a breach of section $8(a)(1) . .^{57}$

50. Alstate Maintenance LLC, supra note 45 at 7.

51. Smith \& Parr, supra note 48 at 374.

52. Ibid.

53. NLRA, supra note $5, \S 158$. ULP charges relating to protected concerted activity are generally brought pursuant to sections $8(\mathrm{a})(1)$ or $8(\mathrm{a})(3)$.

54. NLRB $v$ Wright Line, a Div of Wright Line Inc (1980), 251 NLRB 1083, affd 662 F (2d) 899 (1st Cir 1981). The certification was then later denied. See NLRB $v$ Wright Line, 455 US 989 (1982) [Wright Line].

55. The Wright Line test was recently clarified such that "To meet the General Counsel's initial burden, the evidence of animus must support finding that a causal relationship exists between the employee's protected activity and the employer's adverse action against the employee." Tschiggfrie Properties, 368 NLRB No. 120 at 1 (2019).

56. Wright Line, supra note 54.

57. See NLRB v Elias Bros. Restaurants Inc, 496 F (2d) 1165 at 1167 (6th Cir 1974); Jim Causley Pontiac v NLRB, $620 \mathrm{~F}$ (2d) 122 at 126 (6th Cir 1980). 


\section{B. PROTECTED CONCERTED ACTIVITY AND STRIKES}

NLRA section 13 provides an express statutory right to strike, although limits exist on legal strikes, depending on the object, purpose, timeliness, or conduct of strikers. ${ }^{58}$ Without canvassing the full complexities of NLRA strike law, it can be said that it contains roughly similar limitations on lawful strikes as does Canadian labour law ${ }^{59}$ although several features of strikes under the NLRA that differ from the Canadian approach merit mention here. First, unlike under Canadian labour legislation, "no-strike" provisions prohibiting strikes during the term of a collective agreement or imposing procedural requirements for a strike to be lawful are not found in the NLRA, but are generally negotiated in agreements. ${ }^{60}$ Where a strike breaches a no-strike provision, it is not protected activity. In such cases, striking employees can be disciplined, including terminated without the employer committing a ULP. ${ }^{61}$ Strike activity can also fall within the scope of NLRA section 7, including strikes over unsafe working conditions, which can protect strikers, including non-unionized employees, from employer retaliation, termination, or permanent replacement. ${ }^{62}$

Second, under the NLRA, striking employees have less protection from permanent replacement than under Canadian labour law. The NLRB distinguishes between lawful strikes that are either "economic" or "ULP"; employees' rights to return to work vary with the type of strike, and a strike may convert from one type to another. ${ }^{63}$ Economic strikes seek to gain an economic concession from the employer, including improved working conditions. Economic strikers cannot be terminated, although they can be permanently replaced and they have limited rights to reinstatement. In contrast, ULP strikes respond to an action by the employer. ULP strikers cannot be terminated nor permanently replaced

58. Section 13 provides that "[n]othing in this Act ... except as specifically provided for herein, shall be construed so as either to interfere with or impede or diminish in any way the right to strike or to affect the limitations or qualifications on that right." See National Labor Relations Board, "The Right to Strike” (n.d.), online: <www.nlrb.gov/strikes> [perma.cc/66TG-82FV].

59. Treatment of secondary strikes is a notable exception but not addressed here as it is not germane to this discussion. See also Brishen Rogers \& Simon Archer, "Protecting Concerted Action Outside the Union Context" (2017) 20 Can Lab \& Emp LJ 141 at 153-54 (general discussion of strikes).

60. See e.g. OLRA, supra note 6 , ss 46,79 . An exception is NLRA, ${ }^{\S} 8(\mathrm{~g})$ (imposing a pre-strike notice period for health care workers).

61. National Labor Relations Board, supra note 58.

62. See Washington Aluminum, supra note 36; Tamara, supra note 44.

63. In contrast, Canadian labour law provides more substantial rights to return to work and protection from permanent replacement. See e.g. OLRA, supra note 6 , s 80 (reinstatement). 
and they have greater rights to reinstatement than economic strikers. ${ }^{64}$ This applies to both unionized and non-unionized striking employees. NLRA section 7 strikes, particularly the pandemic strikes addressed here, are likely considered to be economic strikes, as they seek to compel the employer to improve working conditions.

Finally, unlike Canadian labour law, the NLRB distinguishes between "repeated" strikes, in which each incidence relates to a separate employer act or problem, which are protected, and "intermittent" strikes, which don't relate to a separate employer act or problem, and which are utilized for the purpose of being more damaging to the employer or less taxing for the employees. These types of strikes are not protected. ${ }^{65}$ Describing the boundary between protected repeated strikes and unprotected intermittent strikes as "hazy," Duff notes that this could be problematic for non-unionized employees, as they may not realize that such a distinction exists. ${ }^{66}$

In sum, NLRA section 7 protection of strike activity may be available to unionized employees without a "no-strike" clause and to non-unionized employees, but is not available to non-employees or workers otherwise outside of the scope of the NLRA. However, as detailed by Brishen Rogers and Simon Archer, protected concerted activity, at least as it operates within the NLRA, has several important shortcomings including: limitations on the scope of protected conduct; imbalance between employers' and employees' entitlements; inadequate enforcement and remedies; and the de jure or de facto exclusion of many workers from the scope of the legislation. ${ }^{67}$

\section{STRIKES AND ABNORMALLY DANGEROUS CONDITIONS}

A second NLRA provision available to protect both unionized and non-unionized employees who are within the scope of the NLRA is the seldom litigated section 502. It operates to prevent employee actions that would otherwise constitute a strike under the NLRA from being considered to be a strike, converting them into a non-strike work stoppage for the purposes of the Act by providing that:

64. National Labor Relations Board, supra note 58.

65. See Duff, supra note 35 at 18-19. Duff provides a detailed explanation of these principles. See also Walmart Stores Inc, 368 NLRB No 24 (2019). Duff contends that this recent decision may expand the application of the intermittent strike concept.

66. Duff, supra note 35 at 11, 18, 29. Duff outlines recommendations for an explicit rebuttable presumption to apply in such cases.

67. Rogers \& Archer, supra note 59 at 153-60. The authors also identify some limitations arising from competition law and common law. See also Duff, supra note 35 at 9, 46-47. Duff outlines competition law constraints, particularly with respect to independent contractors. 
the quitting of labor by an employee or employees in good faith because of abnormally dangerous conditions for work at the place of employment of such employee or employees [shall not] be deemed a strike under this Act. ${ }^{68}$

Protecting a work stoppage from constituting a strike under the NLRA is particularly significant for unionized employees with "no-strike" clauses in their collective agreements, because the employees will then not have violated this agreement provision and, therefore, they will not be subject to an injunction, civil liability, permanent replacement, or termination, although employers can still use temporary replacement workers. ${ }^{69}$

In order for section 502 to protect a work stoppage, it must be demonstrated on a preponderance of evidence that:

the employees believed in good-faith that their working conditions were abnormally dangerous; that their belief was a contributing cause of the work stoppage; that the employees' belief is supported by ascertainable, objective evidence; and that the perceived danger posed an immediate threat of harm to employee health or safety. ${ }^{70}$

An "abnormally dangerous" working condition is an "identifiable, presently existing threat to the employees' safety," though can include "risks that are ordinarily present [that have] intensified," but don't include risks that are inherent in the job..$^{71}$ Neither a "subjective impression or danger" nor a "speculative doubt about safety in general" will be sufficient. ${ }^{72}$ Notably, safety concerns need not be the sole motivation for the work stoppage, ${ }^{73}$ and there is no requirement that the activity be concerted; therefore, it is available to individual employees.

\section{NLRA PROTECTIONS FOR STRIKERS}

In sum, the NLRA contains two provisions - section 7 protected concerted activity and section 502 abnormally dangerous conditions work stoppages — which can be relevant to strike activity and to health and safety related strikes in particular. These provisions operate in different ways. NLRA section 7, applicable to a broad array of concerted action for mutual aid or protection, provides protection

68. NLRA, supra note $5,{ }^{\S} 143$.

69. Duff, supra note 35 at 16; TNS Inc, 329 NLRB 602 (1999) [TNS Inc].

70. Ibid. See also Gateway Coal Co v United Mine Workers of America, 414 US 368 at 386-87 (1974) [Gateway].

71. Gateway, supra note 70 at 386; TNS Inc, supra note 69 at 607; Carl H Coleman, "Beyond the Call of Duty: Compelling Health Care Professionals to Work during an Influenza Pandemic" (2008) 94 Iowa L Rev 1 at 16.

72. TNS Inc, supra note 69 at 607.

73. Ibid. 
to strike activity, sheltering employees from retaliation and employment consequences through the ULP provisions. It requires only a good-faith belief by employees in the complaint underlying the action, which need not be objectively reasonable or wholly correct. Section 502 applies only to employee action that would otherwise be a strike, causing it to be treated as a non-strike work stoppage instead, thereby protecting employees from consequences of an unlawful strike, which would arise from violating a "no-strike" collective agreement clause. The test for section 502 protection is more stringent than that for section 7 . The section 7 test is "essentially a subjective standard," while section 502 work refusals must be based on "ascertainable, objective evidence of an abnormally dangerous condition." " Section 502 requires a good-faith belief in "abnormally dangerous" working conditions posing an immediate threat, and demonstration of "ascertainable, objective evidence." 75 Therefore, section 502 is of greater use to unionized employees with a "no-strike" clause in their collective agreements. Both provisions are available to unionized employees and non-unionized employees alike. Non-employee workers - such as independent contractors, or those excluded from application of the Act—do not have access to these protections.

\section{EMPLOYEE FREEDOMS AND STRIKES UNDER CANADIAN LABOUR LAW}

Utilizing the OLRA as broadly representative of Canadian labour legislation, this section outlines the opportunities, protections, and consequences for three categories of workers engaging in strikes over fears of workplace safety: unionized employees, non-unionized employees, and workers such as non-employees who are excluded from the Act.

The modern era of Canadian collective bargaining legislation commenced with passage of PC 1003 in 1944, which became the model for legislation in jurisdictions across the country. PC 1003 adopted elements of the original US "Wagner Act" NLRA, passed in $1935 .{ }^{76}$ Consequently, Canadian labour legislation is commonly referred to as "Wagner model" legislation. However, labour legislation in Canada developed in a very different social, economic, and

74. These contrast with the subjective-objective standard required for occupational health and safety work refusal, which must be both in good faith and have a reasonable basis. See Mark A Rothstein, Occupational Safety and Health Law, 2020 ed (Thomson West) § 20:6.

75. TNS Inc, supra note 69.

76. "Wagner model," refers to the US NLRA as it was originally passed in 1935 , reflecting the name of its key sponsor, Senator Wagner. 
political context than had the NLRA, and it departs from the Wagner model and the current NLRA in several important respects, particularly with regard to the scope of employee freedoms and regulation of strikes. ${ }^{77}$ In contrast with the NLRA's emphasis on statutory rights, Canadian labour legislation focused on ensuring industrial peace, and suppressing strikes and worker militancy. The fundamental deal struck with labour in modern Canadian collective bargaining legislation is that union recognition and collective bargaining are provided in exchange for restrictive union certification and strikes. ${ }^{78}$ These differences in orientation and purpose are reflected in the texts of the statutes, and several of these differences are crucial to this discussion.

In addition to the narrower scope of application of the legislation addressed above, ${ }^{79}$ the three statutory elements relevant to strikes in Canadian labour legislation are addressed below: the fundamental freedoms provision; limits and preconditions for lawful strikes, giving rise to an implied right to strike; protections for unionized employees in a legal strike, including that employment is not deemed to cease due to striking, in conjunction with right to return to work protections and ULP protections for employee freedom and rights under the Act. Treatment by the OLRA of strikes by non-unionized workers is then addressed.

\section{A. FREEDOM TO JOIN AND PARTICIPATE IN A TRADE UNION}

The OLRA analogue to the NLRA section 7 protected concerted activity provision, as the linchpin of employee rights in the statute, is section 5 of the OLRA. As interpreted by the Ontario Labour Relations Board (OLRB), section 5 promises that every employee "is free to join a trade union of the person's own choice and to participate in its lawful activities." ${ }^{" 80}$ As such, it guarantees a significantly narrower scope of activities than does section 7 , with the scope of

77. See John Godard, "Labour Law and Union Recognition in Canada: A HistoricalInstitutionalist Perspective” (2013) 38 Queen's LJ 391 (presenting a historical-institutionalist analysis of the reasons for and future implications of these differences); Barry Eidlin, Labor and the Class Idea in the United States and Canada (Cambridge University Press, 2018) (examining the origins of these differences).

78. Eidlin, supra note 77 at 233-34; see also Judy Fudge and Eric Tucker, "The Freedom to Strike in Canada: A Brief Legal History” (2009) 15 Can Lab \& Emp LJ 333 at 348-52.

79. See Part III of this article, supra.

80. Although section 5 speaks of "every person," the OLRB interprets this section as applying only to "employees." See Brian Langille, "What Is a Strike" (2009) 15 Can Lab \& Emp LJ 355 at 365-66, citing Communications Workers of Canada v AAS Telecommunications Ltd, [1976] OLRB Rep 751; Jarvis v Associated Medical Services Inc, [1964] SCR 497. 
protection limited to union-related activity by employees, and does not address non-unionized collective employee activities other than seeking to unionize.

The basic structure of the OLRA is that employees (including dependent contractors) fall within the statute, unless they are explicitly excluded. Common exclusions are managers, confidential labour relations workers, and specified occupational and professional exclusions. ${ }^{81}$ Under the OLRA, excluded workers cannot be "employees" within the meaning of the Act and, therefore, are not subject to provisions applicable only to employees. ${ }^{82}$ The Act is administered and enforced by the OLRB.

\section{B. REGULATION OF STRIKES}

In contrast with section 13 of the NLRA, the right to strike is not explicitly included in Canadian labour legislation or common law. Instead, as George Adams says, it "seems to have been implied into existence." 83 The legislation incorporates a broad view of what constitutes strike activity. In common with almost all Canadian jurisdictions, the OLRA contains an "objective" definition of strike: "includ[ing] a cessation of work, a refusal to work or to continue to work by employees in combination or in concert or in accordance with a common understanding, or a slow-down or other concerted activity on the part of employees designed to restrict or limit output." ${ }^{\text {84 }}$

81. OLRA, supra note 6, ss 1(3), 3. According to Langille, employees coming within each of these types of exclusions are treated the same by the OLRA with respect to strikes. See Langille, supra note 80.

82. Langille, supra note 80.

83. George W Adams, Canadian Labour Law, 2nd ed (Aurora, ON: Canada Law Book, 1993) (loose-leaf, updated 2020, release 80) at 11.90. However, the Supreme Court of Canada recently recognized strikes as falling within the scope of the Charter s 2(d) guarantee of freedom of association, accepting that strikes are a necessary part of the process of collective bargaining. See Saskatchewan Federation of Labour v Saskatchewan, 2015 SCC 4.

84. OLRA, supra note 6, s 1 . In contrast, collective bargaining legislation in Alberta, Manitoba, and Nova Scotia include a "subjective" element in the definition of "strike," requiring that the activity have as a purpose compelling the employer to settle a collective agreement. See Labour Relations Code, RSA 2000, c L-1, s 1(v); Labour Relations Act, RSM 1987, c L10, s 1; Trade Union Act, RSNS 1989, c 475, s 2(1)(v). Few jurisdictions exclude specified types of activity from being considered a strike. Only British Columbia and New Brunswick exempt legal work refusals pursuant to workplace health and safety legislation from the strike definition. See Labour Relations Code, RSBC 1996, c 244, s 1(1) [BC Labour Relations Code]; Industrial Relations Act, RSNB 1973, c I-4, s 1(1)). However, a work stoppage based on a "disingenuous" safety concern can constitute a strike even in those jurisdictions. See Southam Inc, BCLRB No. B263/2000, rev'd in part BCLRB No. B328/2001. 
Although the definition of strike is broad, and the legislation provides that employment is not deemed to cease only by reasons of striking, an array of statutory restrictions means that a strike is lawful only in limited circumstances. ${ }^{85}$ Strikes are statutorily prohibited during the term of a collective agreement, and a "no-strike" provision must be included in every agreement and is deemed to exist should the agreement fail to include it. ${ }^{86}$ Even when an agreement has expired, two statutory preconditions must be satisfied for a strike to be lawful: a successful strike vote authorizing a strike, and exhaustion of the statutory conciliation process. ${ }^{87}$ Some jurisdictions also require advance written notice of strike commencement. ${ }^{88}$ In contrast, as noted above, such limitations on lawful strike activity are not found in the NLRA, though they may be found in voluntarily negotiated "no-strike" collective agreement provisions.

The combined effect of the strike definition and preconditions for lawful strikes is that the OLRA, in common with legislation in other Canadian jurisdictions, only allows for one type of lawful strike—a bargaining strike—and only in certain, limited circumstances. In contrast, as described above, the NLRA contemplates a wider variety of potentially lawful or protected strikes: recognition and ULP strikes during the term of the agreement, in addition to economic strikes (a category including but broader than Canadian "bargaining" strikes). ${ }^{89}$

\section{OLRA PROTECTION FOR UNIONIZED STRIKERS}

The OLRA guarantees employees the freedom to participate in lawful union activities and explicitly recognizes that the employment relationship continues to exist during lawful strikes. ${ }^{90}$ Striking employees also have substantial return to work rights that, in combination with ULP prohibitions and remedies, provide lawfully striking employees with broad protection from employer retaliation, including permanent replacement. ${ }^{91}$

Employees engaged in lawful strikes are protected from employer retaliation and negative employment consequences by the statute's ULP provisions; such strikes are lawful union activity guaranteed by the basic statutory section 5

85. OLRA, supra note 6, s 1(2).

86. OLRA, supra note 6, s 79(1). Mandatory grievance arbitration, rather than a strike, is the mid-term dispute resolution mechanism under the Canadian system.

87. See e.g. OLRA, supra note 6, ss 79, 79.1 .

88. See e.g. BC Labour Relations Code, supra note 84, s 60(6).

89. "Recognition" refers to employer recognition of a union as the bargaining representative of a group of workers. See Langille, supra note 80 at 360-61 (for a detailed discussion).

90. See e.g. OLRA, supra note 6, ss 1(2), 5.

91. See e.g. ibid, s 80 . 
freedom. ${ }^{92}$ For example, section 72 of the OLRA prohibits employer interference with this freedom by prohibiting an employer from: refusing to employ or continue to employ, or to discriminate against an employee for exercising his or her rights under the OLRA; imposing contract conditions that seek to restrain an employee from joining a union; and, using threats, promises, or other means to compel an employee not to join or to cease membership in a union or not exercise other rights under the OLRA. ${ }^{93}$

A reverse onus applies to the main ULP provisions, such that the employer must establish on the balance of probabilities that its impugned conduct did not have an improper motive- that is, that it was not motivated in whole or in part by anti-union animus or related to union activity. ${ }^{94}$ Labour boards have broad jurisdiction to award compensatory remedies for ULP violations. An important limitation, and a key difference between US and Canadian collective bargaining legislation, is that these protections are available to employees during union organizing and once unionized, but not to employees who are neither unionized nor in the process of seeking union representation. ${ }^{95}$

In the case of an unlawful strike, in addition to consequences for a union, individual employees may be subject to discipline, may be found to have violated statutory prohibitions on doing anything to cause an illegal strike, or may contravene a board illegal strike declaration or cease and desist order. Individuals or unions violating the legislation or any labour board decision, order, direction, or similar are subject to significant statutory monetary penalties, which accrue on a daily basis for each day that the contravention continues. ${ }^{96}$ Meanwhile the collective agreement and grievance arbitration machinery continue to apply, and the employer may still utilize the doctrine of fundamental breach. ${ }^{97}$

92. Canadian Pacific Railway Co v Zambri, [1962] SCR 609 [Zambri] (strikes are protected by the $s$ freedom).

93. OLRA, supra note 6, s 72; Adams, supra note 83 at para 10.110. Additional ULP provisions prohibit: employer participation in or interference with the formation; selection or administration of, or representation by, a trade union (OLRA, supra note 6, s 70); intimidation or coercion to compel any person regarding union membership or exercising rights or obligations under the OLRA ( $i b i d, s 76$ ); persuading during working hours to join or not join a union (ibid, s 77); direct employer bargaining with union members (ibid, s 73(1)); or, strike-breaking activities (ibid, s 78(1)).

94. OLRA, supra note 6, s 96(5); Adams, supra note 83 at para 10.120.

95. Rogers \& Archer, supra note 59 at 148.

96. See e.g. OLRA, supra note 6, s 104.

97. OLRA, supra note 6, s 83; Adams, supra note 83 at para 11.90; McGavin Toastmaster v Ainscough, [1976] 1 SCR 718. Additional consequences outside of labour law, including competition law, common law tort, and contract law, may also be relevant. 


\section{STRIKES BY NON-UNIONIZED WORKERS UNDER THE OLRA}

It is clear that the full array of protections and consequences under the OLRA is available to unionized employees engaging in lawful or unlawful strikes. However, whether and to what extent there exists a right to strike, and consequences for unlawful strikes, by non-unionized employees or for workers excluded from the statutory regime (such as independent contractors), are much more complicated questions under Canadian labour law than under the NLRA. ${ }^{98}$ Brian Langille notes that this is an "obscure" part of our law, and that "the dominance of the statutory scheme has orphaned any real legal analysis of strikes outside the statute, i.e., at common law. As a result, most of us have forgotten how to think about these matters." ${ }^{\prime 9}$

So, where does this leave workers who are explicitly excluded from the OLRA, non-employees such as independent contractors, and workers who are employees but not unionized nor seeking to unionize?

\section{STRIKES BY WORKERS EXCLUDED FROM THE OLRA}

Employees explicitly excluded from the OLRA do not have the benefit of section 5 employee freedoms, which includes the freedom to strike. ${ }^{100}$ As a result, they lack the benefit of the basic ULP provisions. In the same way that the NLRA section 8(a)(1) ULP provision reflects the specific language of NLRA section 7, the main OLRA ULPs (sections 72 and 76) reflect section 5, including the specific and far narrower language of the freedoms provided compared to the NLRA section 7. The OLRA provides employees only the freedom to "join a trade union of [their] own choice and to participate in its lawful activities." Correspondingly, the ULP provisions protect these freedoms, including other rights under the Act, from various types of violations: threats, promises, terminations, et cetera. What the OLRA neither promises as a freedom nor promises to protect are other forms of collective activity for workers ineligible to access section 5 freedoms. ${ }^{101}$

98. This article does not address the Charter with respect to these questions, although see the conclusion for some comments in this regard.

99. Langille, supra note 80 at 356 .

100. OLRA, supra note 6, ss 1(3), 3. Section 1(3) provides that certain persons-such as managers, confidential employees, and specified professionals—shall not be deemed to be "employees"; s 3 provides that the OLRA does not apply to certain occupations or specified groups.

101. The main ULP provisions apply to persons, and section 97 of OLRA specifies that this includes non-employees excluded by section 1(3) but not those excluded by section 3 . However, because ULPs effectuate the section 5 freedoms and the OLRB continues to interpret the section 5 freedoms as applying only to "employees," the result is that neither category of excluded worker, in effect, has protection of the main ULP provisions. See OLRA, supra note 6, ss 1(3), 3, 5, 97; Langille, supra note 80 at 362-69. 
However, these workers are not subject to the timeliness restrictions on legal strikes, which only apply to "employees." Therefore, these workers are free of any statutory restrictions on strikes but are also free of any statutory protections for strikes. ${ }^{102}$ Consequently, these workers are governed by common law, and may face common law consequences for strike activity, ${ }^{103}$ as well as consequences arising from non-labour statutes, such as competition law. Langille describes the common law right to strike as follows:

[I] $\mathrm{t}$ is the freedom of a group of workers, playing by the rules of contract termination, and acting for a certain purpose (i.e., (re)negotiations of their contract with the employer), to stop working in an effort to get the employer to come to terms. ... But it is purely a freedom at common law, and one not protected by a perimeter of rights. ${ }^{104}$

Langille asserts that, therefore, the key distinction between the statutory and common law freedoms to strike is the protection afforded by ULP provisions to the former. ${ }^{105}$ Workers subject only to the common law freedom to strike have no protection from employer retaliation or termination, and the employer has no obligation to reinstate or not to terminate these workers except as may arise from these workers' individual contracts of employment or for service with the employer.

\section{STRIKES BY NON-EMPLOYEES}

For the same reasons (lack of access to section 5 statutory freedom to strike, with the consequent lack of protection for this freedom), non-employees such as independent contractors would be in the same position as workers explicitly excluded from the OLRA. As described above, they would be subject to the common law freedom to strike, and would be subject to all of the risks and consequences this might bring.

\section{STRIKES BY NON-UNIONIZED EMPLOYEES}

What, then, is the position of non-unionized employees who are not otherwise excluded from the OLRA? This may be the trickiest question, and it is the one most central to this inquiry. Unlike the types of workers described above (those excluded by sections 1(3) or 3 of the Act, or who are not "employees" within the

102. Langille, supra note 80 at 364; OLRA, supra note 6, ss 1(3), 3. Langille is referring to workers excluded pursuant to the OLRA, ss 1(3), 3 .

103. Langille, supra note 80 at 368.

104. Ibid at 368-69, citing Zambri, supra note 92.

105. Ibid at 369 . 
meaning of the Act), non-unionized employees likely have access to the section 5 freedoms, including the freedom to strike, even under the OLRB's restrictive reading of this provision, and the main ULPs are available to such employees. So, on the face of it, it appears that these non-unionized employees may be in a similar situation as they would be under section 7 of the NLRA. This is the case, insofar as section 5 freedoms apply. As noted above, however, these freedoms are much narrower than the NLRA section 7 protected concerted activity guarantee. With regard to strikes, OLRA section 5 only includes lawful strikes as a form of "participation in lawful union activity," and the relevant ULP protections, similarly, protect only lawful strikes. Therefore, only strikes that constitute a lawful activity of a trade union would fall within OLRA section 5 or the ULP provisions meant to ensure those freedoms.

Assuming that non-unionized employees would not, or could not, satisfy the statutory prerequisites for a lawful strike applicable to employees, such a strike would not be lawful. Therefore, the fundamental freedom of union membership and ULP provisions would not be available to offer these employees any recourse for or protection from employer retaliation, including discipline or discharge. ${ }^{106}$ This lack of protection or recourse is true, more generally, of collective action taken by non-unionized employees in Canada and is not limited to strike activity. Minimum standards legislation and the common law of employment, to the extent that it would be applicable in any given case, would be their only recourse. ${ }^{107}$ Consequently, non-unionized employees would end up in the same position as excluded workers and non-employees-able only to exercise the common law freedom to strike, without statutory protections and with all the risks and liabilities this may bring.

\section{REVISITING PANDEMIC-RELATED STRIKES IN THE UNITED STATES AND CANADA}

Returning to the pandemic-related worker actions in the US and Canada described at the outset of this article, the apparent differences between the countries in workers' collective protests against unsafe working conditions can be explained by key differences between US and Canadian labour legislation.

106. Given the focus here on labour law, consequences of unlawful strike activity beyond labour law are not addressed here.

107. See Langille, supra note 80 (regarding Canadian common law perspectives on strike activity). See Rogers \& Archer, supra note 59 at 148 (for a summary of minimum standards legislation anti-retaliation provisions). 
In the US, there were multiple incidents of non-unionized employees engaging in multiple forms of collective actions, including single-location and mass strikes. Some employees involved did suffer negative employment consequences and have claimed employer retaliation for participating in these actions. In many of these cases, it is likely that the NLRA section 7 protected concerted activity guarantee is applicable, which can be enforced through the Act's ULP provisions. Indeed, media reports that multiple ULP charges have been filed in many of these cases.

Addressing some of the same US pandemic work stoppages discussed here, Duff notes that NLRA section 7 protection likely protects those strikes relating to health and safety, as they are concerted activity that has a "tight connection to work condition." ${ }^{108}$ However, writing in 2008, Carl Coleman considered whether risks arising from a pandemic would qualify as "abnormally dangerous" in health care workplaces, specifically. He suggested that most of these workers could credibly claim that to be the case, but speculated that the courts may focus on foreseeable risk rather than on whether it is out of the ordinary, in which case health care work in a pandemic would not likely satisfy section 502. ${ }^{109}$

While NLRA section 502 may also be available in such cases, as explained above, the benefit of the "non-strike work stoppage" designation this provision provides is primarily of value to unionized workers with "no-strike" provisions in their collective agreements. Given the limited scope of application and more onerous test for application of NLRA section 502 compared to section 7, it is more likely that these non-union actions were undertaken, or subsequently defended, pursuant to the protected concerted activity provision of the NLRA. Therefore, these non-unionized employees engaging in strikes were doing so with the same protection as (and, compared to unionized employees, subject to a "no-strike" clause, greater freedom than) unionized employees.

In contrast, in Canada, we have not seen pandemic-related strikes by either non-unionized or unionized employees. Indeed, some non-unionized employees sought out media to publicize their concerns, expressing fear of employer retaliation. Even in the context of unionized workplaces, we have seen unions explicitly state that their actions were not strikes.

As outlined above, and unlike under the NLRA, the scope for lawful, statutorily protected strike action is very narrow under Canadian labour law. Non-unionized employees have no means of accessing statutory strike protection. In the case of unionized employees, unless no collective agreement was in force

108. Duff, supra note 35 at 15.

109. Coleman, supra note 71 at 16. 
and the various preconditions for a lawful strike had been satisfied (and they most likely were not in these cases), any strike would have been illegal, exposing the union and employees to an array of consequences. Therefore, non-unionized workers in Canada would be very unlikely to strike and would have no statutory labour law protection from employer retaliation or negative employment consequences, and so are likely very wary of taking any public action. The limited scope for lawful strikes and the significant consequences to unions and employees of unlawful strikes are clear in the case of unionized employees, and explain why we have seen unions with unionized employees engaging in pandemic collective action emphasize that these actions were not strikes.

\section{CONTEMPLATING PROTECTED CONCERTED ACTIVITY FOR CANADIAN EMPLOYEES}

As William Corbett notes, "The scope of coverage of section 7 and its application to non-union employees may have been one of the best-kept secrets of labor law. It also may be one of the best means for protecting employee rights in the United States in the twenty-first century." 110 Moreover, Lance Compa has pointed out that NLRA concerted activity protections are even more favourable to workers than International Labour Organization (ILO) standards because they protect "any form of 'concerted activity ... for mutual aid and protection,' not just union activity." 111

Others, including more recently Rogers and Archer, have suggested that Canadian labour legislation be amended to incorporate protection akin to the NLRA's protected concerted activity provision. ${ }^{112}$ Focusing on the scope for such an amendment to support activities of workers' centres that represent non-unionized employees, these authors didn't address in detail necessary ancillary amendments, or strike regulation, in particular. However, Rogers and Archer contend that the "roughly symmetrical" relevant norms and processes under Canadian and US labour legislation suggest that there would be no significant impediments to adopting a provision similar to NLRA section 7 into Canadian labour legislation, and that such an addition would not significantly disrupt Canadian labour law or labour relations. ${ }^{113}$ They further suggest that such an amendment would be

110. William R Corbett, "Waiting For the Labor Law of the Twenty-First Century: Everything Old Is New Again” (2002) 23 Berkeley J Emp \& Lab L 259 at 267.

111. Compa, supra note 34 at 437.

112. Rogers \& Archer, supra note 59.

113. Ibid at 160-61. 
consistent with Canada's international law commitments and with the Charter of Rights and Freedoms guarantee of freedom of association. ${ }^{114}$

If Canadian labour legislation, such as the OLRA, was to be amended to include a guarantee of protection for concerted activity, what might that entail, not only with respect to statutory strikes, but also for other elements of the Canadian Wagner model? First, some straightforward technical amendments to the freedoms provision and to key ULP provisions would be necessary. Second, if this guarantee is to extend covering strikes as a form of protected concerted activity, some more complex changes and policy decisions would be necessary. These would include the scope of application of labour legislation including the nature of collective worker action it contemplates, and whether to provide a concrete foundation for minority unionism in labour legislation.

\section{A. ESTABLISHING THE GUARANTEE}

In order to establish protection for concerted activity, it would be necessary to amend the employee freedoms provision (section 5) to cover the more expansive range of activities encompassed by the NLRA section 7, reaching beyond organizing and collective bargaining to employee actions for "mutual aid or protection." Such an amendment could simply involve adopting the language of section 7 in place of, or in addition to, the existing employee freedom language. As noted earlier, although the existing OLRA freedom provision applies to "every person," this provision is interpreted more narrowly, to apply only to employees. Given that the Supreme Court of Canada and ILO bodies regard freedom of association as a guarantee that is not limited to employees, this would be an opportunity to re-establish a greater breadth of application for the section 5 freedom provision. ${ }^{15}$

Because employee freedoms are effectuated by the ULP provisions of the Act, it would also be necessary to amend these provisions (in particular, OLRA

114. Note that others, including David Doorey "Graduated Freedom of Association: Worker Voice Beyond the Wagner Model” (2013) 38 Queen's L.J. 511, and Alison Braley-Rattai "Harnessing the Possibilities of Minority Unionism in Canada" (2013) 38 Lab Stud J 321, identify section 7 of NLRA as reference points in their respective proposals for introducing supplementary forms of minority unionism into Canadian labour law systems, although neither addresses strikes as protected concerted activity.

115. Breen Creighton \& Shae McCrystal "Who Is a Worker in International Law" (2015) 37 Comp Lab L \& Pol'y J 691; Beatriz Vacotto, "Precarious Work and the Exercise of Freedom of Association and Collective Bargaining: Current ILO Jurisprudence" (2013) 5 Intl J Labor Res 117; ILO, Freedom of Association and Protection of the Right to Organize Convention, 1948 (No. 87); ILO, Right to Organize and Collective Bargaining Convention, 1949 (No. 98). 
sections 72 and 76) to reflect the expanded scope of employee freedoms. To avoid interpretive difficulties, legislatures may consider adopting the approach taken in the NLRA. There, the relevant ULP provision (NLRA section 8(a)(1)) explicitly refers to the protected concerted activity guarantee, providing that it would be a ULP for an employer "to interfere with, restrain, or coerce employees in the exercise of the rights guaranteed in [NLRA] section 7." As both the OLRA and the NLRA apply a reverse onus for such ULPs, no further change to ULP processes or provisions would be required. ${ }^{116}$

\section{B. STRIKES AND PICKETING}

In respect of strikes, the more interventionist and restrictive approach of Canadian labour legislation, compared to the NLRA, poses some challenges to extending a guarantee of protected concerted activity to strike activity in Canadian statutes. This may require policymakers to make some decisions about whether to continue with the Canadian practice of tightly regulating strikes and permitting only limited types of strikes, subject to numerous statutory preconditions, to be lawful. This is a departure that Canadian labour law has taken from the Wagner model, and diverges from the less interventionist approach taken by the NLRA to strikes. As explained above, the NLRA permits more types of strikes than does Canadian labour law and, rather than imposing preconditions on strikes to be lawful, leaves it to the bargaining parties to negotiate "no-strike" provisions in their collective agreements. Canadian policymakers may wish to consider whether, as under the NLRA, recognition or ULP strikes, in addition to bargaining strikes, could be lawful and whether, or to what degree, to leave it to the parties to impose limits or preconditions on strike activity. If a more restrictive approach to strikes is to be maintained, then explicit exceptions to the expanded employee freedom provision would be necessary to account for such limitations on concerted activity.

In addition, and in any event for greater clarity and in consideration of the recent Supreme Court decision regarding the Charter protected right to strike,

116. Although beyond the scope of this article, in light of recent Charter decisions regarding freedom of association protection of collective bargaining rights and Canada's obligations under international law, expansion of application of employee freedoms beyond "employees" within the meaning of the Act may be due for consideration, as well as reconsideration of statutory exclusions from the Act. See Michael Lynk, A Review of the Employee Occupational Exclusions under the Ontario Labour Relations Act, 1995 (Queen's Printer for Ontario, 2016). This report was prepared for the Ontario Ministry of Labour regarding continuing justifiability of exclusions of non-employees and others from labour legislation in Canada. 
legislators might contemplate adding an explicit right to strike to the legislation, as exists in NLRA section 13. ${ }^{117}$

Finally, alongside strikes, the separate but often related activities of picketing and leafleting should also be contemplated as forms of protected concerted activity. While both are recognized as meriting Charter protection, if not under the freedom of association then the freedom of expression, picketing is subject to statutory regulation to different degrees in different Canadian jurisdictions. ${ }^{118}$ In jurisdictions such as Ontario, where the legislation does not directly regulate picketing activity and picketing is largely governed by common law, amendments may not be necessary. ${ }^{119}$

\section{DIFFICULT QUESTIONS}

Finally, contemplating introducing protection for concerted activity into Canadian labour legislation may also give rise to some more difficult and fundamental policy questions.

First, as seen in the examples introducing this article, NLRA section 7 can be utilized by employees for short-lived collective action that is divorced from the goals of union organizing or an ongoing collective bargaining relationship. However, Canadian labour legislation and interpretations of the Charter freedom of association are oriented towards establishing and engaging in an enduring "collective bargaining relationship" between employers and trade union representatives of groups of workers. ${ }^{120}$ In contemplating incorporating protection akin to NLRA section 7 into Canadian labour legislation, these US experiences should prompt us to reflect on whether this unconventional (by Canadian labour law standards, at least) form of associational activity-reflecting mobilizing rather than organizing — reveals a different type of representation gap

117. Saskatchewan Federation of Labour $v$ Saskatchewan, 2015 SCC 4.

118. U.F.C.W., Local 1518 v KMart Canada Ltd, [1999] 2 SCR 1083 (leafleting); R.W.D.S.U., Local 558 v Pepsi-Cola Canada Beverages (West) Ltd, 2002 SCC 8 (secondary picketing).

119. In Ontario, picketing may give rise to a ULP under the OLRA where, for instance, it gives rise to a sympathy strike by other employees or the picketing involves threatening or coercive conduct. See OLRA, supra note 6, ss 76, 83. In jurisdictions, such as British Columbia, where the statute does govern picketing, amendments would be necessary. See BC Labour Relations Code, supra note 84, Part 5, for an example of statutory regulation of picketing.

120. This type of collective action likely constitutes collective bargaining as it is understood by international labour law as these actions are for the purpose of pursuing employees' workplace goals they likely constitute collective bargaining. See Collective Bargaining Convention, 1981 (No. 154), International Labour Organization, 3 June 1981, Art 2. 
affecting Canadian workers that should be addressed. ${ }^{121}$ The experiences and examples of US employees suggest that short-lived associational activity may be of fundamental value to workers in a way that is distinct from conventional organizing and collective bargaining and, as such, is worthy of explicit protection.

Second, introducing protection for concerted activity raises the question of whether policymakers are prepared to provide a statutory foundation for minority unionism in Canadian labour legislation. Minority unionism involves provision of representation or bargaining rights to a union as a result of having agreement (typically through membership) of less than a majority of employees. Neither certification nor majority support is required. The most commonly discussed form of minority unionism is "members-only" unionism, whereby the union is able to represent only its members. Under the NLRA, section 7 is the explicit foundation for minority unionism. As currently interpreted by the NLRB and courts, it permits, but does not require, members-only minority unionism, such that an employer may, but is not required to, bargain with such unions. ${ }^{122}$

Currently, Canadian labour law does not prohibit voluntary employee representation on a minority basis, much in the same way that most labour legislation permits voluntary recognition without expressly providing for it. Several scholars have advocated for forms of minority unionism to be adopted into or alongside existing Canadian labour legislation, arguing that doing so would be consistent with, or even required by, international law and the Charter guarantee of freedom of association. ${ }^{123}$ However, critics caution against potentially destabilizing and undesirable effects of minority unionism, and jurists have been

121. On the distinction between mobilizing and organizing in the labour context, see Jane Holgate, Melanie Simms \& Maite Tapia "The limitations of the theory and practice of mobilization in trade union organizing" (2018) 39 Econ \& Indus Democracy 599.

122. Catherine Fisk $\&$ Xenia Tashlitsky "Imagine a world where employers are required to bargain with minority unions” (2011) 27 ABA J Lab \& Emp L 1. Some scholars, most notably Charles J Morris, The Blue Eagle at Work: Reclaiming Democratic Rights in the American Workplace (Ithaca, NY: ILR Press, 2005), contend that the text and legislative history of section 7 of NLRA supports mandatory minority union bargaining.

123. See e.g. Doorey, supra note 114; Braley-Rattai, supra note 114; Roy J Adams "Bringing Canada's Wagner Act Regime into Compliance with International Human Rights Law and the Charter" (2015) 19 Can Lab \& Emp LJ 365; Mark Harcourt \& Peter Haynes "Accommodating minority unionism: Does the New Zealand experience provide options for Canadian law reform" (2011) 16 Can Lab \& Emp LJ 51. 
wary of the potential chaos that could arise from employers facing bargaining with multiple unions. ${ }^{124}$

\section{VII.CONCLUSION}

While the COVID-19 pandemic and the associated worker activity arising from fears of unsafe working conditions during this time have brought this labour law secret into the headlines, it has also highlighted an important, but often overlooked, difference in employee protections between US and Canadian labour law. This difference centres on the narrow statutory freedoms granted by Canadian labour law, compared to the broader scope and application of the NLRA section 7 protected concerted activity guarantee. Although the pandemic is, hopefully, a passing episode, the importance of protected concerted activity for non-unionized workers should be an enduring concern.

124. See e.g. Fisk \& Tashlitsky, supra note 122; Brad Walchuk "The Pitfalls of Embracing Minority Unionism" (2016) 6 J Workplace Rights 1; Compa, supra note 34. For discussion of Canadian jurists' trepidation about minority unionism, see Adams, supra note 83; Fraser $v$ Ontario $(A G), 2008$ ONCA 760 at para 92; Ontario $(A G) v$ Fraser, 2011 SCC 20 at paras 346-51. 
